\title{
The influence of aqueous and hydro-alcoholic extracts of roots and rhizomes of Rhodiola kirilowii on the course of pregnancy in mice
}

\author{
ROBERT ZDANOWSKI ${ }^{1}$, SŁAWOMIR LEWICKI ${ }^{1}$ KATARZYNA SIKORSKA', \\ MAGDALENA ŻMIGRODZKA ${ }^{1}$, WALDEMAR BUCHWALD', JACEK WILCZAK', \\ EWA SKOPIŃSKA-RÓŻEWSKA \\ ${ }^{1}$ Department of Regenerative Medicine, Military Institute of Hygiene and Epidemiology, Warsaw, Poland \\ ${ }^{2}$ Department of Botany, Breeding and Agriculture, Institute of Natural Fibres and Medicinal Plants, Poznań, Poland \\ ${ }^{3}$ Department of Physiological Sciences, Faculty of Veterinary Medicine, Warsaw University of Life Sciences, Warsaw, Poland \\ ${ }^{4}$ Pathology Department, Biostructure Center, Warsaw Medical University, Warsaw, Poland
}

\begin{abstract}
Plants belonging to the Rhodiola genus, originating from Asia, are traditionally used as tonic, adaptogen, antidepressant and anti-inflammatory drugs. These plants have also potent immunomodulatory properties and in some situations possibly could be used instead of standard antibiotic therapy (e.g. during pregnancy or lactation). The aim of our present study was to establish whether aqueous $(R K W)$ or hydro-alcoholic ( $R K W-A)$ extracts from roots and rhizomes of Rhodiola kirilowii given to pregnant mice influence the course of pregnancy and the number of progeny. Performed HPLC analysis showed that the RKW-A extract had a generally higher concentration of all identified polyphenols. The highest differences were observed for (+)-catechin, p-coumaric acid and naringenin. Everyday addition of the RKW or RKW-A extract did not change the length of pregnancy. At the same time, both RKW and $R K W$-A extracts significantly increased the number of mated females without offspring but only in the $R K W-A$ group we noticed a few neonatal deaths in the first 5 days after delivery. The results reported in the present study do not encourage to the use of R. kirilowii hydro-alcoholic extracts supplementation during pregnancy and lactation, however the possibility of limited dietary intake of R. kirilowii water extract should be thoroughly examined.
\end{abstract}

Key words: Rhodiola kirilowii, pregnancy, chemical analysis.

(Centr Eur J Immunol 2014; 39 (4): 471-475)

\section{Introduction}

Treatment of infections in pregnant women is a serious problem. Conventional therapy with antibiotics may negatively influence various parameters of progeny health. Skopińska-Różewska et al. showed that some antibiotics administered to the experimental model of pregnant mice changed the reactivity of their offspring immune system $[1,2]$.

Plant-based immune stimulation provides an alternative to conventional therapy. Some of plant extracts, however, may be dangerous because they contain various potentially anti-angiogenic substances which may disturb fetus development. A group of potentially non-toxic natural drugs having multiple pharmacological actions, originating from traditional sources are plants belonging to the Rhodiola genus ( $R$. rosea, $R$. quadrifida, $R$. kirilowii) [3]. We have performed studies on the immunotropic activity of hydro-alcoholic and aqueous extracts of roots and rhizomes of these plants in mice, rats and pigs and we obtained evidence of stimulation of various parameters of cellular and humoral immunity [4-9]. However, all these extracts (except one) significantly suppressed tumor angiogenesis induced in syngeneic mice after grafting of L-1 sarcoma cells. This non-inhibitory extract was the aqueous extract of Rhodiola kirilowii obtained from its underground parts [10]. In view of this finding it is possible that the aqueous $R$. kirilowii extract might not impair embryonic angiogenesis as well, and would be not dangerous for fetus development. So, we supposed that it might be possible to use the $R$. kirilowii aqueous extract during pregnancy as a safe immune enhancer. The aim of the present study was to establish whether aqueous and hydro-alcoholic $R$. kirilowii extracts given to pregnant mice will change the course of pregnancy and the number of progeny.

Correspondence: Sławomir Lewicki, PhD, Department of Regenerative Medicine, Military Institute of Hygiene and Epidemiology, Kozielska 4, 01-163 Warsaw, Poland, e-mail: lewickis@gmail.com 


\section{Material and methods}

\section{Plant cultivation}

Rhodiola kirilowii (Crassulaceae) roots and rhizomes were cultivated, collected and identified in the Research Institute of Medicinal Plants (RIMP), presently the Institute of Natural Fibres and Medicinal Plants, Poznań. The cultivation was established by vegetative propagation. The plant growth was controlled: the reaction and mineral components of the soil, air temperature, average humidity, and rain as well as sun periods were monitored permanently. A voucher specimen is kept in the herbarium of the Department of Botany, Breeding and Agriculture in Plewiska near Poznań.

\section{Preparation of extracts}

Water extract (RKW): finely powdered roots were extracted two times with water (first -2 hours and second -1 hour long) in the ratio of raw material/solvent of $1 / 5$, at a temperature of $40-45^{\circ} \mathrm{C}$. The supernatants were mixed together, spun and lyophilized.

Hydro-alcoholic extract (RKW-A): finely powdered roots were extracted with ethanol/water solution $(1 / 1, \mathrm{v} / \mathrm{v})$ in the ratio of raw material/solvent of $1 / 10$ by the percolation method. Then, the percolates were lyophilized which was preceded by the distilling off the ethanol at a temperature of $40-45^{\circ} \mathrm{C}$.

Dry extract ratio (DER) values were: $5.09 / 1$ for RKW and $3.27 / 1$ for RKW-A. Extracts were stored at $-70^{\circ} \mathrm{C}$ until used.

\section{Chemical analysis of extracts}

Total extracts' polyphenols/flavonoids concentration was assayed by applying the HPLC system (Dionex) equipped in the CoulArray electrochemical detector (ESA Inc.). The extraction procedure of polyphenols/flavonoids was performed according to the method proposed by Hertog et al. [11]. Briefly, $0.1 \mathrm{~g}$ of a sample was refluxed using $5 \mathrm{ml}$ of $50 \%$ aqueous methanol at $40^{\circ} \mathrm{C}$ for two hours. This solution contains $1.5 \mathrm{~g} / \mathrm{l}$ of butylated hydroxy anisol (BHA) in order to prevent the analytes from oxidation. The obtained extracts were filtered by a $0.45 \mu \mathrm{m}$ syringe Millipore filters and injected into the HPLC system. The separation was conducted on a Hypersil BDS $150 \times 4.6 \mathrm{~mm}$, $5 \mu \mathrm{m}$ column (Sigma-Aldrich) at a mobile phase flow rate of $1.2 \mathrm{ml} / \mathrm{min}$. The mobile phase consisted of sodium phosphate $50 \mathrm{mM}$ : methanol $(99: 1) \mathrm{pH} 3.0$. The conditions of electrochemical detection: four electrodes with potentials $400,500,600$, and $750 \mathrm{mV}$.

\section{Animals}

Experiments were performed in 96 adult inbred females of Balb/c strain, 8-9 weeks old, mated with adult males from the same strain. Females, since a copulatory plug was noted, up to the $28^{\text {th }}$ day after delivery were fed daily with lyophilized RKW or RKW-A extracts $(20 \mathrm{mg} / \mathrm{kg}$ b.m.) dissolved in distilled water. The dose of extracts corresponds to $200 \mathrm{mg}$ given to a $70-\mathrm{kg}$ person, applying the coefficient equal 7 for adjusting differences between the mouse and human in relation of the surface to body mass. The control group received distilled water. The substances were applied on corn crisps and served to the female in a Petri dish.

For all performed experiments animals were handled according to the Polish regulation concerning the wellness of laboratory animals (Polish National Institute of Health) standards. All experiments were accepted and conducted according to ethical guidelines of the Local Bioethical Committee. Mice were maintained under conventional conditions in IVC cages (room temperature $22-23^{\circ} \mathrm{C}$, relative humidity $50 \pm 10 \%, 12 \mathrm{~h}$ day/night cycle) with free access to breeding rodent feed (Labofeed $\mathrm{H}$, Wytwórnia Pasz "Morawski") and water.

\section{Statistical analysis}

Statistical evaluation of the results obtained in the control and experimental groups comprised a proportion of mothers to non-pregnant mated females and the mean litter size. Comparisons of controls and RKW and RKW-A extracts were made by $\chi^{2}$ analysis and one way ANOVA with Tukey's multiple comparison post-test (Graph Pad Prism).

\section{Results}

\section{Chemical analysis of extracts}

Results of analysis of polyphenols/flavonoids from R. kirilowii extracts are presented in Table 1. HPLC-ECD analysis revealed significant differences in the content of biologically selected active compounds between the RKW and RKW-A extracts. Generally, the RKW-A extract had a higher concentration of all identified polyphenols and flavonoids. The lowest differences were observed for quercetin (18\%), ferulic acid (30\%) and salidroside (35\%) while the highest differences were observed for (+)-catechin (119\%), p-coumaric acid (126\%) and naringenin (127\%).

\section{Pregnancy and offspring analysis}

Length of pregnancy in control mice ranged from 19 to 23 days (with mean at 20.5). Addition of RKW or RKW-A extract did not change statistically this parameter. Average length of pregnancy in mice supplemented with RKW extracts amounted to 20.2, and with RKW-A 20.9 days. Interestingly, we noted one mouse from RKW-A group which had an abnormally long pregnancy time (42 days). The progeny (2 mice) survived for four days only. 
Addition of R. kirilowii extracts (both RKW as well as RKW-A) significantly increased the number of mated females without offspring ( $p<0.05$, Fig. 1). The ratio of mated females with offspring to the mated females without offspring was 24/11 in control, 13/18 in RKW and 13/17 in RKW-A group.

Rhodiola kirilowii hydro-alcoholic extract caused a significant increase in the litter size (Fig. 2) in comparison to the progeny of RKW $(p<0.01)$ and control $(p<0.05)$ mice. However, we noticed some mortality in the first 5 days after delivery in the progeny of mothers fed with RKW-A extracts; approximately $8.5 \%$ (6 of 71 newborns). In the RKW (54) or control group (105), all newborns survived.

\section{Discussion}

The genus Rhodiola (Crassulaceae) consists of more than 100 species. They grow in the Arctic regions and in the mountains of the Northem Hemisphere and are traditionally used as tonic, adaptogen, antidepressant and anti-inflammatory drugs. The best known is $R$. rosea, now cultivated also in Europe and North America, and present on the market as a dietary supplement. A number of clinical trials demonstrate that repeated administration of this plant extracts increases mental performance and reduces burnout in patients with a fatigue syndrome. Lack of interaction with other drugs and lack of adverse effects in the course in clinical trials make it potentially attractive for use as a safe medication [12, 13]. Rhodiola kirilowii has similar properties. The plant is used in the Chinese traditional medicine as adaptogen for the enhancement of

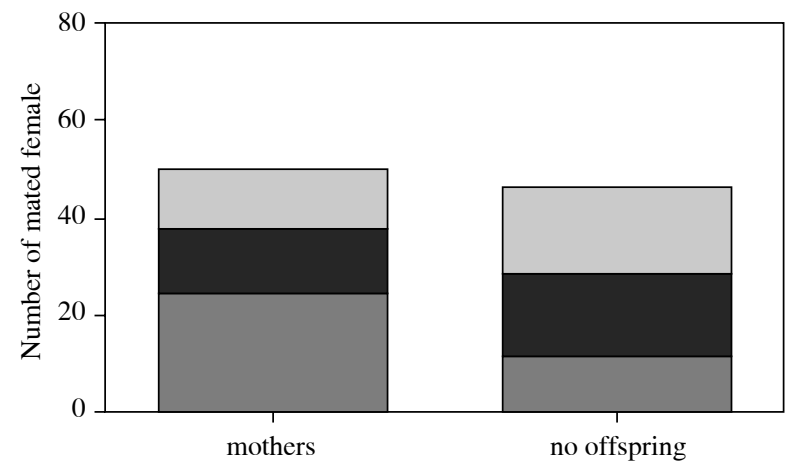

\begin{tabular}{cccc}
\hline $\begin{array}{c}\text { Mated } \\
\text { females }\end{array}$ & Control & RKW & RKW-A \\
\hline with offspring & 24 & 13 & 13 \\
\hline no offspring & 11 & 18 & 17 \\
\hline$\chi^{2}$ & & $6.012,2$ & \\
\hline$p$-value & & 0.0495 & \\
\hline
\end{tabular}

Table 1. Chemical analysis of polyphenols/flavonoids from Rhodiola kirilowii extracts. Two extracts were examined: RKW (water extract) and RKW-A (hydro-alcoholic extract). Analysis was performed in triplicate by high-performance liquid chromatography connected with electrochemical detector (HPLC-ECD). Results are presented as mean $(\mu \mathrm{g} / \mathrm{mg}$ of dry extract) and SEM. a, b, c - significant differences of RKW-A in comparison to RKW extract $(p<0.05 ; p<0.01 ; p<0.001$, respectively)

\begin{tabular}{lcccc}
\hline & \multicolumn{2}{c}{ RKW } & \multicolumn{2}{c}{ RKW-A } \\
\cline { 2 - 5 } & Mean & SEM & Mean & SEM \\
\hline Salidroside & 2.62 & 0.12 & $3.56^{\mathrm{a}}$ & 0.34 \\
\hline Fisetin & 0.80 & 0.03 & $1.11^{\mathrm{c}}$ & 0.03 \\
\hline Naringenin & 0.04 & 0.00 & $0.09^{\mathrm{c}}$ & 0.01 \\
\hline Kaempferol & 0.64 & 0.02 & $1.06^{\mathrm{c}}$ & 0.03 \\
\hline Epicatechin & 2.66 & 0.10 & $4.44^{\mathrm{c}}$ & 0.06 \\
\hline Luteolin & 0.04 & 0.00 & $0.08^{\mathrm{b}}$ & 0.01 \\
\hline p-coumaric acid & 0.39 & 0.02 & $0.87^{\mathrm{c}}$ & 0.04 \\
\hline Ellagic acid & 0.68 & 0.02 & $1.08^{\mathrm{c}}$ & 0.03 \\
\hline Quercetin & 1.88 & 0.05 & $2.22^{\mathrm{b}}$ & 0.05 \\
\hline Epigallocatechin & 1.34 & 0.04 & $1.90^{\mathrm{c}}$ & 0.06 \\
\hline Ferulic acid & 0.93 & 0.04 & $1.21^{\mathrm{c}}$ & 0.03 \\
\hline Chlorogenic acid & 1.02 & 0.01 & $1.50^{\mathrm{c}}$ & 0.01 \\
\hline (+)-catechin & 0.90 & 0.02 & $1.96^{\mathrm{c}}$ & 0.01 \\
\hline
\end{tabular}

Total number of mated female mice: 96

$$
\begin{aligned}
& \square \text { Control } \\
& \square \text { RKW-A } \\
& \square \text { RKW }
\end{aligned}
$$

Fig. 1. Results of mated females supplemented during pregnancy with lyophilized Rhodiola kirilowii extracts. Two extracts - RKW (water extract) and RKW-A (water-alcoholic extract) were used in a dose of $20 \mathrm{mg} / \mathrm{kg}$ b.m. Mice with a copulatory plug were considered "mated females". Table shows the statistical analysis of the results 


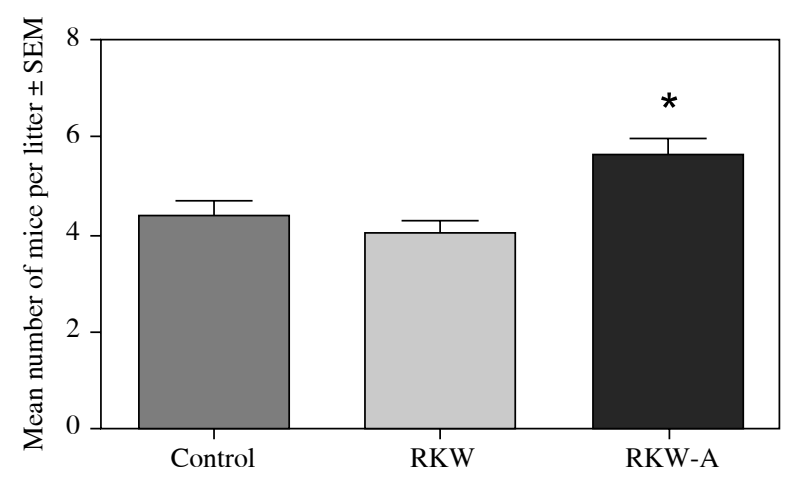

*statistical differences

$$
\begin{array}{ll}
\text { Total number of progeny: } & 230 \\
\text { Control vs. RKW-A: } & p<0.05 \\
\text { RKW vs. RKW-A: } & p<0.01
\end{array}
$$

Fig. 2. Mean litter size. Mother mice were supplemented during pregnancy with lyophilized Rhodiola kirilowii extracts. Two extracts - RKW (water extract) and RKW-A (water-alcoholic extract) were used in a dose of $20 \mathrm{mg} / \mathrm{kg}$ b.m.

the ability of anti-anoxia. Rhodiola kirilowii has also immunomodulatory properties and therefore could be used as an anti-bacterial or anti-fungal drug.

There is insufficient knowledge about the effects of using herbal drugs during pregnancy. While some data indicate that fetal malformations do not occur during pregnancy in humans consuming immunotropic herbs (for example Echinacea species well known for their immune-enhancing effect), there have been no formal studies aimed at assessing whether consuming Echinacea remedies may promote congenital abnormalities or fetal growth retardation. In our previous experiments we found that commercially available Echinacea-containing drugs lowered the number of embryos in some litters [14]. Also Chow and co-workers indicated in a mice model that consuming E. purpurea during pregnancy reduced the number of viable fetuses [15]. In the present study aqueous and hydro-alcoholic extracts administered to mated females affect some parameters of pregnancy. This applied to the litter size (significant increase after RKW-A supplementation) as well as the number of females without offspring (significant increase after both extracts supplementation). The second observation is severely hazardous because it may indicate aberrations in early fetal development or engraftment of the fetus. Moreover, in offspring of mothers fed with RKW-A, approximately $8.5 \%$ mortality of newborns was noted, what was not observed in control or RKW fed mothers. This may additionally provide evidence for $a b-$ normality in fetal development during pregnancy.

Explanation of this negative influence on pregnancy and fetal development is in the chemical constituents of the extract. It is well known that the R. kirilowii plant has a variety of chemical compounds, e.g. phenylethanoids (salidroside, p-tyrosol), flavonoids (epicatechin, epigallocatechin gallate, luteolin, quercetin), phenolic acids (p-coumaric, chlorogenic, ferulic) tannins, and many others [16]. Those compounds exhibit various biological activities which may affect fetal and post-natal development. In previous studies performed on the pregnancy model, we tested the effects of feeding pregnant and lactating mice with theobromine, caffeic acid or chocolate on humoral and cellular immune response of their 6-week-old progeny. We also investigated the effects of these compounds and a mixture of cocoa catechins on the angiogenic activity of 19-day embryos tissues. Feeding pregnant mice with these substances decreased relative length of limbs and thigh bones in the 4-week-old progeny, with accompanying bone mineralization disturbances. Angiogenic activity of embryonic tissues correlated negatively with their epigallocatechin content. In six-week-old progeny of mice fed with chocolate, theobromine or caffeic acid we observed morphological (kidneys, bones) and immunological abnormalities [17-21]. We supposed that chocolate catechins (also present in small amounts in R. kirilowii extracts) may play an important role in these post-natal abnormalities. According to this, some authors report embryotoxic effects of green tea catechins, epigallocatechin-3-gallate and epicatechin gallate [22, 23]. In addition, experiments performed on the model of serum induced angiogenesis (SIA) and cytokine- induced angiogenesis (CIA) confirmed the anti-angiogenic activity of several compounds of plant origin (ursolic acid, epigallocatechin, epigallocatechin gallate and others) [24-26]. Evaluation of selected polyphenols and flavonoids from the R. kirilowii extract (aqueous and hydro-alcoholic) performed in the present study demonstrated a significantly higher concentration of compounds in RKW-A extracts. The enhanced mortality effect in offspring observed after application of this extract may be caused by an increased concentration of one compound (e.g. catechin, epigallocatechin, epicatechin or chlorogenic acid) or a specific mixture of compounds. This effect could be also caused by other compounds not indicated in the present study. However, for the future analysis of the effect of $R$. kirilowii extracts used during pregnancy and lactation on pregnancy parameters and fetal development, some standardization should be made. In our opinion, the most favorable standardization is for salidroside, catechin or epigallocatechin concentration (similarly as the $R$. rosea commercially available supplement is standardized for salidroside and rosavin concentration).

\section{Conclusions}

The results reported in the present study do not encourage to the use of $R$. kirilowii hydro-alcoholic extracts supplementation during pregnancy and lactation, however the 
possibility of limited dietary intake of $R$. kirilowii water extract should be resolved by its further studies. Research into the compound or special group of compounds responsible for adverse effects on the developing fertility should be undertaken.

The authors declare no conflict of interest.

This work was supported by grant of the National Centre of Science 2012/05/B/NZ7/03219.

\section{References}

1. Skopińska-Różewska E, Barcz E (2007): Wpływ substancji naturalnych i syntetycznych podawanych w okresie ciąży na rozwój układu odpornościowego potomstwa - badania na modelu ciężarnej myszy. In: Aktualne problemy immunodiagnostyki i immunotoksykologii. Siwicki AK, Skopińska-Różewska E (eds.). SPW Edycja, Olsztyn; 37-50.

2. Skopińska-Różewska E, Makuch K (2010): Use of diet supplements, synthetic drugs and herbal remedies with immunotropic activity during pregnancy. I. Echinacea. Centr Eur J Immunol 35: 183-185.

3. Kosanovic D, Tian X, Pak O, et al. (2013): Rhodiola: an ordinary plant or a promising future therapy for pulmonary hypertension? a brief review. Pulm Circ 3: 499-506. doi: $10.1086 / 674303$.

4. Skopińska-Różewska E, Furmanowa M, Siwicki AK, et al. (2005): The influence of different Rhodiola extracts on cellular immunity in mice and pigs. Herba Polonica 51 (SI): 170.

5. Siwicki AK, Skopińska-Różewska E, Hartwich M, et al. (2007): The influence of Rhodiola rosea extracts on non-specific and specific cellular immunity in pigs, rats and mice. Centr Eur J Immunol 32: 84-91.

6. Skopińska-Różewska E, Wójcik R, Siwicki AK, et al. (2008): The effect of Rhodiola quadrifida extracts on cellular immunity in mice and rats. Pol J Vet Sci 11: 105-111.

7. Wójcik R, Siwicki AK, Skopińska-Rózewska E, et al. (2009): The effect of Chinese medicinal herb Rhodiola kirilowii extracts on cellular immunity in mice and rats. Pol J Vet Sci 12: 399-405.

8. Skopińska-Różewska E, Stankiewicz W, Zdanowski R, et al. (2012): The in vivo effect of Rhodiola quadrifida extracts on the antibody production, on the blood leukocytes subpopulations and on the bacterial infection in mice. Centr Eur J Immunol 37: 140-144.

9. Zdanowski R, Lewicki S, Skopińska-Różewska E, et al. (2014): Alcohol- and water-based extracts obtained from Rhodiola rosea affect differently the number and metabolic activity of circulating granulocytes in Balb/c mice. Ann Agric Environ Med 21: 120-123.

10. Zdanowski R, Skopinska-Różewska E, Wasiutyński A, et al. (2012): The effect of Rhodiola kirilowii extracts on tumor-induced angiogenesis in mice. Centr Eur J Immunol 37: 131-139.

11. Hertog MC, Hollman PCH, Venema DP (1992): Optimization of a quantitative HPLC determination of potentially anticarcinogenic flavonoids in vegetables and fruits. J Agri Food Chem 40: 1591-1598.

12. Hung SK, Perry R, Ernst E (2011): The effectiveness and efficacy of Rhodiola rosea L.: a systematic review of ran- domized clinical trials. Phytomedicine 18: 235-244. doi: 10.1016/j.phymed.2010.08.014.

13. Ishaque S, Shamseer L, Bukutu C, Vohra S (2012): Rhodiola rosea for physical and mental fatigue: a systematic review. BMC Complement Altern Med 12: 70. doi: 10.1186/14726882-12-70.

14. Barcz E, Sommer E, Nartowska J, et al. (2007): Influence of Echinacea purpurea intake during pregnancy on fetal growth and tissue angiogenic activity. Folia Histochem Cytobiol 45 Suppl 1: 35-39.

15. Chow G, Johns T, Miller SC (2006): Dietary Echinacea purpurea during murine pregnancy: effect on maternal hemopoiesis and fetal growth. Biol Neonate 89: 133-138.

16. Krajewska-Patan A, Furmanowa M, Dreger M, et al. (2008): Rhodiola kirilowii - the present status and perspectives of medicinal use. Part I. In vivo and in vitro cultivation as well as phytochemical investigations of extracts of roots and callus tissues. Herba Polonica 4: 140-157.

17. Skopiński P, Skopińska-Rózewska E, Sommer E, et al. (2003): Chocolate feeding of pregnant mice influences length of limbs of their progeny. Pol J Vet Sci 6 (3 Suppl): 57-59.

18. Skopiński P, Skopińska-Różewska E, Kamiński A, et al. (2004): Chocolate feeding of pregnant mice resulted in epigallocatechin- related embryonic angiogenesis suppression and bone mineralization disorder. Pol J Vet Sci 7 (3 Suppl): 131-133.

19. Rogala E, Skopińska-Różewska E, Wojtasik E, et al. (2004): Caffeic acid feeding of pregnant mice influences the prenatal development of their offspring. Pol J Vet Sci 7 (3 Suppl): 101-103.

20. Wasiutyński A, Siwicki AK, Bałan BJ, et al. (2005): Inhibitory effect of cocoa catechins on embryonic and tumor angiogenesis in mice. Pol J Environm Studies 14 (Supll II): 800-805.

21. Patera J, Chorostowska-Wynimko J, Słodkowska J, et al. (2006): Morphometric and functional abnormalities of kidneys in the progeny of mice fed chocolate during pregnancy and lactation. Folia Histochem Cytobiol 44: 207-211.

22. Wang CC, Chu KO, Chong WS, et al. (2007): Tea epigallocatechin-3-gallate increases 8-isoprostane level and induces caudal regression in developing rat embryos. Free Radic Biol Med 43: 519-527.

23. Tu HC, Chen CP, Chan WH (2010): Epicatechin gallate decreases the viability and subsequent embryonic development of mouse blastocysts. Taiwan J Obstet Gynecol 49: 174-180. doi: 10.1016/S1028-4559(10)60037-X.

24. Skopinski P, Szaflik J, Duda-Król B, et al. (2004): Suppression of angiogenic activity of sera from diabetic patients with non-proliferative retinopathy by compounds of herbal origin and sulindac sulfone. Int J Mol Med 14: 707-711.

25. Skopiński P, Skopińska-Różewska E, Sommer E, et al. (2004): Inhibitory effect of complement inactivation and epigallocatechin gallate on the human serum ability to induce cutaneous neovascular reaction in mice. Bull Vet Inst Pulawy 48: 485-487.

26. Skopinski P, Skopinska-Różewska E, Sommer E, et al. (2005): The effect of some diet-derived angiogenesis inhibitors and sulindac sulfone on the ability of VEGF, bFGF and IL-18 to induce cutaneous neo-vascular response in mice. Pol J Environm Studies 14 (Suppl II): 325-329. 